\title{
VALIDASI BAHAN AJAR TRIGONOMETRI DENGAN MODEL INKUIRI BERORIENTASI PENDIDIKAN KARAKTER
}

\author{
Made Juniantari \\ Universitas Pendidikan Ganesha, Jln. Udayana No.11 Singaraja \\ e-mail: mdjuniantari@undiksha.ac.id
}

\begin{abstract}
Validation Trigonometri Teaching Materials with Inquiry Model Based On Character Education. This study aims to developing valid trigonometry teaching materials with inquiry model based on character education to improve student's critical thinking skills at Department of Mathematics Education Undiksha. Plomp's development procedure was applied to conduct the study which consist of five stages, namely: (1) preliminary investigation, (2) design, (3) realization/construction, (4) test, evaluation, and revision, and (5) implementation. In the first year, this study has reached the stage of testing, evaluation, and revision to determine the validity of teaching materials. The validity of the content can be viewed on the suitability of teaching materials developed by the theory of the development and characteristics of the learning model. The validity of the construct can be viewed on the appropriateness of each component of teaching materials with the characteristics of the learning model which obtained from the expert. The construct validity of teaching materials is very valid. Advice from validator used as a reference for the revision of teaching materials. The next step is doing limited implementation to see the practicality and effectiveness of teaching materials.
\end{abstract}

Keyword: trigonometry's teaching materials, inquiry model, character education

\begin{abstract}
Abstrak: Validasi Bahan Ajar Trigonometri dengan Model Inkuiri Berorientasi Pendidikan Karakter. Penelitian ini bertujuan untuk mengembangkan bahan ajar trigonometri dengan model inkuiri berorientasi pendidikan karakter yang valid untuk meningkatkan kemampuan berpikir kritis mahasiswa Jurusan Pendidikan Matematika Undiksha. Pengembangan bahan ajar dalam penelitian ini mengikuti prosedur pengembangan dari Plomp yang meliputi lima tahap yaitu: (1) investigasi awal, (2) desain, (3) realisasi/konstruksi, (4) tes, evaluasi, dan revisi, dan (5) implementasi. Pada tahun pertama penelitian ini dilakukan sampai pada tahap tes, evaluasi, dan revisi yaitu melakukan validasi bahan ajar. Validitas isi dilihat dari kesesuaian bahan ajar dengan teori pengembangan yang dijadikan pedoman dan sesuai dengan tuntutan karakteristik model pembelajaran. Validitas konstruk dilihat dari adanya keterkaitan yang konsisten dari setiap komponen bahan ajar yang dikembangkan dengan karakteristik model pembelajaran yang diperoleh melalui penilaian validator. Validasi konstruk bahan ajar yang telah dikembangkan termasuk katagori sangat valid. Berdasarkan penilaian validator kemudian dilakukan revisi bahan ajar. Tahap selanjutnya adalah tahap uji coba terbatas untuk melihat kepraktisan dan keefektivan bahan ajar.
\end{abstract}

Kata kunci: bahan ajar trigonometri, model inkuiri, pendidikan karakter

Pendidikan karakter adalah suatu sistem penanaman nilai-nilai kebaikan kepada warga sekolah atau kampus yang meliputi komponen pengetahuan dan sikap untuk membentuk manusia yang berkarakter sesuai dengan nilainilai luhur Pancasila (Zuchdi, 2012). Pelaksanaan pendidikan karakter di Universitas Pendidikan Ganesha (Undiksha) terus mengalami perkembangan. Hal ini dilaksanakan dalam upaya untuk mewujudkan semboyan Undiksha yaitu "Dharmaning sajjana umerdhyaken widyaguna", yang artinya: kewajiban orang bijaksana adalah mengembangkan ilmu pengetahuan dan pekerti." Untuk dapat menghayati dan mewujudkan makna yang tersirat dari semboyan tersebut, diperlukan pengintegrasian pendidikan karakter ke dalam kegiatan tri dharma perguruan tinggi yaitu pendidikan, penelitian, dan pengabdian kepada masyarakat. 
Undiksha adalah salah satu universitas negeri di Indonesia yang giat dalam mencetak calon guru profesional, unggul, dan berkarakter. Profesional mengandung arti bahwa calon guru harus menguasai bidang keilmuannya, dan berkarakter mengandung arti bahwa calon guru harus memiliki sikap sebagai teladan bagi peserta didiknya. Bagaimanapun juga pribadi yang kuat dan mulia akan menjadi tauladan yang baik bagi lingkungan sekitarnya.

$$
\text { Jurusan Pendidikan Matematika }
$$

Undiksha juga senantiasa berupaya dengan komitmen yang kuat untuk selalu berbenah diri dalam mencetak calon guru matematika yang profesional dan berkarakter. Upaya tersebut tidaklah selalu berjalan mulus. Banyak kendala pembelajaran dihadapi yang mengakibatkan mahasiswa susah dalam memahami materi. Permasalahan tersebut hampir terjadi di setiap mata kuliah, salah satunya mata kuliah Trigonometri dengan bobot 2 SKS yang merupakan katagori mata kuliah dasar dan menjadi prasyarat mata kuliah lainnya dalam rumpun ilmu matematika. Berdasarkan data yang diambil pada bagian sistem informasi Puskom Undiksha Tanggal 19 Oktober 2015 diperoleh data bahwa pada tahun akademik 2013/2014 sebanyak 20,95\% mahasiswa memperoleh nilai $\mathrm{A}, 33,11 \%$ nilai $\mathrm{B}, 27,03 \%$ nilai $\mathrm{C}, 10,14 \%$ nilai $\mathrm{D}$, dan $8,78 \%$ nilai $\mathrm{E}$. Sedangkan pada tahun akademik 2014/2015 sebanyak 4,55\% mahasiswa memperoleh nilai A, $22,08 \%$ nilai $\mathrm{B}, 37,01 \%$ nilai $\mathrm{C}, 27,92 \%$ nilai D, dan $8,44 \%$ nilai E. Dari data tersebut pada tahun akademik 2013/2014 sebanyak $45,95 \%$ mahasiswa belum memiliki pemahaman yang baik terhadap konsep trigonometri sedangkan pada tahun akademik 2014/2015 meningkat menjadi 73,37\%.

Rendahnya kemampuan mahasiswa dalam memahami konsep trigonometri ini disebabkan oleh beberapa faktor. Pertama, berdasarkan hasil tes awal yang dilakukan, mahasiswa mengalami kesulitan dalam menemukan konsep matematis dan pembuktian identitas trigonometri yang memerlukan konsentrasi dan interaksi yang tinggi dalam pembelajaran meliputi kegiatan mencari, menyelidiki dan pembuktian secara sistematis, kritis, logis, dan analitis. Permasalahan yang kedua, melalui wawancara dengan dosen pengampu mata kuliah trigonometri, kurang berhasilnya mahasiswa dalam pembelajaran trigonometri salah satunya disebabkan oleh rendahnya kesadaran mahasiswa terhadap tugas utamanya sebagai mahasiswa yaitu bertanggung jawab terhadap keberhasilan belajarnya dan kemajuan dirinya. Permasalahan ini mencerminkan karakter mahasiswa masih perlu pembinaan. Permasalahan yang ketiga, berdasarkan hasil wawancara dengan beberapa mahasiswa yang mengambil mata kuliah trigonometri adalah kurang tersedianya bahan ajar yang dapat memfasilitasi mereka mengeksplorasi dengan maksimal segala pengetahuannya untuk sampai pada konsep yang mereka pelajari.

Menurut Khan (2012) "inquiri is one way of knowing" yang berarti suatu cara untuk mengetahui. Apabila seseorang terkait dalam proses investigasi, berusaha menjawab pertanyaan, dan berusaha memecahkan masalah secara berkelanjutan, maka orang tersebut telah melakukan inkuiri. Artinya proses inkuri mengandung proses-proses mental yang lebih tinggi tingkatannya, misalnya merumuskan masalah, merancang eksperimen, melakukan eksperimen, mengumpulkan dan menganalisis data, menarik simpulan, dan sebagainya. Model inkuiri ini sangat cocok diterapkan mengingat sifat mata kuliah trigonometri yang lebih banyak menekankan pada pembentukan konsep matematis dan pembuktian identitas trigonometri yang menuntut mahasiswa untuk memiliki kemampuan berpikir kritis.

Menurut Sudiarta (2008) berpikir kritis merupakan salah satu jenis berpikir yang divergen yang berkaitan dengan bagaimana mengkonstruksi segala kemungkinan jawaban yang reasonable, beserta segala kemungkinan prosedur dan argumentasinya yang masuk akal (how to construct and to defend various reasonable solutions and its respective procedures). Kemampuan berpikir kritis sangatlah cocok dilatih pada mata kuliah trigonometri mengingat cara membuktikan identitas trigonometri tidaklah tunggal. Mahasiswa bisa menggunakan berbagai langkah pembuktian yang berbeda-beda tetapi sampai pada pembuktian yang tepat.

Model inkuiri merupakan model pembelajaran yang berupaya menanamkan dasar-dasar berpikir ilmiah pada diri peserta didik, sehingga dalam pembelajaran peserta didik dapat mengembangkan kreativitasnya dalam memecahkan masalah. Adapun fase pembelajaran dengan model inkuiri yang sesuai dengan karakteristik materi trigonometri adalah perumusan masalah, perumusan hipotesis, melakukan penyelidikan, menganalisis hasil 
penyelidikan, dan membuat simpulan. Pembelajaran yang bercirikan inkuiri mengandung makna suatu rangkaian kegiatan belajar yang melibatkan secara maksimal seluruh kemampuan peserta didik untuk mencari dan menyelildiki secara sistematis, kritis, logis, analitis, sehingga mereka dapat merumuskan sendiri penemuan dengan penuh percaya diri.

Sasaran utama kegiatan inkuiri untuk mahasiswa jurusan pendidikan matematika yang mengikuti pembelajaran trigonometri lebih menekankan pada: (1) keterlibatan mahasiswa secara maksimal dalam pembelajaran, (2) keterarahan kegiatan secara logis dan sistematis sehingga sampai pada tujuan pembelajaran, dan (3) mengembangkan sikap karakter mahasiswa sebagai upaya pengintegrasian pendidikan karakter melalui proses inkuiri.

Merujuk pada permasalahan kedua, dosen perlu menerapkan pembelajaran yang mengacu pada 18 nilai karakter yang perlu ditanamkan yang bersumber dari Agama, Pancasila, Budaya, dan Tujuan Pendidikan Nasional (Kemendiknas, 2011). Kedelapan belas nilai tersebut adalah: (1) religius, (2) jujur, (3) toleransi, (4) disiplin, (5) kerja keras, (6) kreatif, (7) mandiri, (8) demokratis, (9) rasa ingin tahu, (10) semangat kebangsaan, (11) cinta tanah air, (12) menghargai prestasi, (13) bersahabat/komunikatif, (14) cinta damai, (15) gemar membaca, (16) peduli lingkungan, (17) peduli sosial, (18) tanggung jawab. Meskipun telah dirumuskan ada 18 nilai pembentuk karakter bangsa, di setiap satuan pendidikan dapat menentukan prioritas pengembangannya. Menurut Thonmas Lickona (2012) dalam pendidikan karakter menyangkut 3 aspek yaitu: pengetahuan moral (moral knowing), perasaan moral (moral feeling) dan tindakan moral (moral action). Ketiga aspek tersebut akan sangat mempengaruhi sikap generasi bangsa baik di sekolah maupun di masyarakat. Terlebih lagi apabila kita perhatikan hasil penelitian di Harvard Univesity Amerika Serikat (dalam Subarinah, 2011) yang menyatakan bahwa kesuksesan seseorang hanya ditententukan sekitar $20 \%$ oleh pengetahuan dan kemampuan teknis (hard skill), sedangkan sisanya $80 \%$ oleh kemampuan mengelola diri dan orang lain (soft skill).

Selain itu, Parwati (2011) menyatakan bahwa pembelajaran matematika berlangsung tidak terlepas dari konteks dan nilai-nilai budaya yang berlaku di masyarakat. Pengembangan kompetensi peserta didik dalam pembelajaran inkuiri berorientasi pendidikan karakter meliputi kompetensi dalam pemecahan masalah, penalaran dan komunikasi matematis, melakukan penemuan dan investigasi, konstruksi dan rekonstruksi konsep matematis, serta kemampuan berpikir kritis, kreatif dan produktif, yang melibatkan imajinasi, intuisi secara baik dan bertanggung jawab. Sehingga untuk permasalahan yang dihadapi mahasiswa jurusan pendidikan matematika pada mata kuliah trigonometri maka karakter yang perlu dibina adalah karakter rasa ingin tahu, kreatif, kerja keras, tanggung jawab, dan demokratis yang dapat dibina melalui aktivitas belajar mahasiswa.

Mengingat keterbatasan bahan ajar sebagaimana yang telah disebutkan pada permasalahan ketiga, perlulah dikembangkan suatu bahan ajar mata kuliah trigonometri dengan model inkuiri berorientasi pendidikan karakter untuk meningkatkan kemampuan berpikir kritis mahasiswa. National Center for Vocational Education Research Ltd/National Center for Competency Based Training (dalam Nugraha, dkk, 2013) mendefinisikan bahan ajar sebagai segala bentuk bahan yang digunakan untuk membantu instruktur dalam melaksanakan pembelajaran di kelas. Nieveen (1999) menyatakan terdapat tiga aspek yang perlu diperhatikan dalam menilai kualitas suatu produk yang dihasilkan dalam hal ini adalah bahan ajar yaitu: validitas (validity), kepraktisan (practicality), dan keefektifan (effectiveness).

Berdasarkan uraian tersebut, untuk mengatasi permasalahan yang dihadapi mahasiswa Jurusan Pendidikan Matematika Universitas Pendidikan Ganesha dalam memahami konsep trigonometri, peneliti melakukan penelitian pengembangan bahan ajar dengan model inkuiri berorientasi pendidikan karakter pada mata kuliah Trigonometri sehingga permasalahan yang ingin dijawab adalah "bagaimana mengembangkan dan memperoleh bahan ajar trigonometri dengan model inkuiri berorientasi pendidikan karakter yang valid untuk meningkatkan kemampuan berpikir kritis mahasiswa?" 
METODE

Pengembangan bahan ajar dalam
penelitian ini mengikuti prosedur
pengembangan perangkat pembelajaran
menurut Plomp (1997). Prosedur penelitian
yang dilaksanakan dibagi menjadi empat tahap
yang masing-masing tahap diuraikan lebih
detail sebagai berikut.

Tahap investigasi awal, kegiatan yang dilakukan pada tahap ini adalah menganalisis situasi dan permasalahan yang dihadapi mahasiswa dan dosen pada pembelajaran trigonometri. Hal-hal yang dilakukan adalah: (1) Meninjau hasil belajar mahasiswa pada mata kuliah trigonometri dua tahun terakhir dan mengadakan tes awal pada mahasiswa yang mengambil mata kuliah trigonometri pada semester I (ganjil) tahun akademik 2015/2016. (2) Meninjau proses pembelajaran yang dilaksanakan di kelas. (3) Melakukan wawancara dengan dosen mengenai kendala dalam pembelajaran trigonometri. (4) Meninjau bahan ajar yang digunakan dalam pembelajaran trigonometri. (5) Melakukan investigasi awal lebih lanjut terhadap kemampuan berpikir kritis mahasiswa semester II (genap) tahun akademik 2015/2016 pada materi Trigonometri untuk mendukung data awal yang telah diperoleh pada semester I (ganjil) tahun akademik 2015/2016. Dari hasil analisis diupayakan solusinya dengan melakukan pengkajian terhadap teori-teori yang mendukung dan menganalisis hasil penelitian yang relevan.

Tahap desain, Pada tahap ini, dilakukan suatu upaya untuk mendesain suatu kemungkinan solusi terhadap masalah yang telah didefinisikan pada tahap investigasi awal. Hal-hal yang dilakukan pada tahap ini adalah: (1) meninjau kembali teori-teori yang mendukung untuk memperbaiki kualitas pembelajaran. Dari hasil tinjauan ini, dilakukan suatu upaya menerapkan model inkuiri berorientasi pendidikan karakter. Selain itu, juga diupayakan untuk mengembangkan suatu produk yakni bahan ajar yang mendukung karakteristik pembelajaran yang diterapkan. (2) merancang bahan ajar yang sesuai dengan karakteristik model inkuiri berorientasi pendidikan karakter.
Tahap realisasi, pada tahap ini solusi yang telah didesain direalisasikan untuk bisa menghasilkan suatu prototipe awal. Prototipe yang dihasilkan masih berupa prototipe 1 yaitu bahan ajar trigonometri dengan model inkuiri berorientasi pendidikan karakter yang selanjutnya perlu diuji validitas, kepraktisan, dan keefektivannya.

Tahap tes, evaluasi, dan revisi, Pada tahap ini bahan ajar yang berhasil direalisasikan dilihat kualitasnya. Hal-hal yang dilakukan adalah: (1) menguji validitas bahan ajar yang masih berupa prototipe 1 oleh dua orang pakar (validator). Berdasarkan hasil uji validasi 1 ini kemudian dilakukan revisi sehingga diperoleh bahan ajar dalam bentuk prototipe 2. Setelah diperoleh prototipe 2, kemudian dilakukan uji coba lapangan. (2) Uji coba lapangan dilakukan untuk mengetahui kepraktisan dan efektivitas bahan ajar yang dikembangkan. Kegiatan uji coba lapangan dibagi menjadi dua siklus. Setiap siklus terdiri dari tahap pelaksanaan, observasi dan evaluasi, serta refleksi untuk melihat apakah bahan ajar yang dikembangkan memenuhi kriteria yang diinginkan. Jika belum dilakukan revisi untuk penyempurnaan. Namun, pada tahun pertama penelitian ini telah dilakukan sampai pada tahap tes, evaluasi, dan revisi yaitu melakukan validasi bahan ajar yang dilihat dari validitas isi dan validitas konstruk. Memenuhi validitas isi berarti bahan ajar yang dikembangkan didasarkan suatu teori pengembangan yang dijadikan pegangan atau pedoman dan sesuai dengan tuntutan karakteristik model pembelajaran yang diterapkan. Kemudian validitas konstruk dilihat dari adanya keterkaitan yang konsisten dari setiap komponen bahan ajar yang dikembangkan dengan karakteristik model pembelajaran yang diterapkan. Untuk melihat validitas konstruk dari bahan ajar, dimintakan pendapat para ahli. Pendapat para ahli ini dijadikan ukuran mengenai valid tidaknya bahan ajar yang dikembangkan.

Tahap pengembangan perangkat pembelajaran menurut Plomp (dalam Sadra, 2007) yang dilaksanakan dalam penelitian ini dapat diamati pada Gambar 1. 


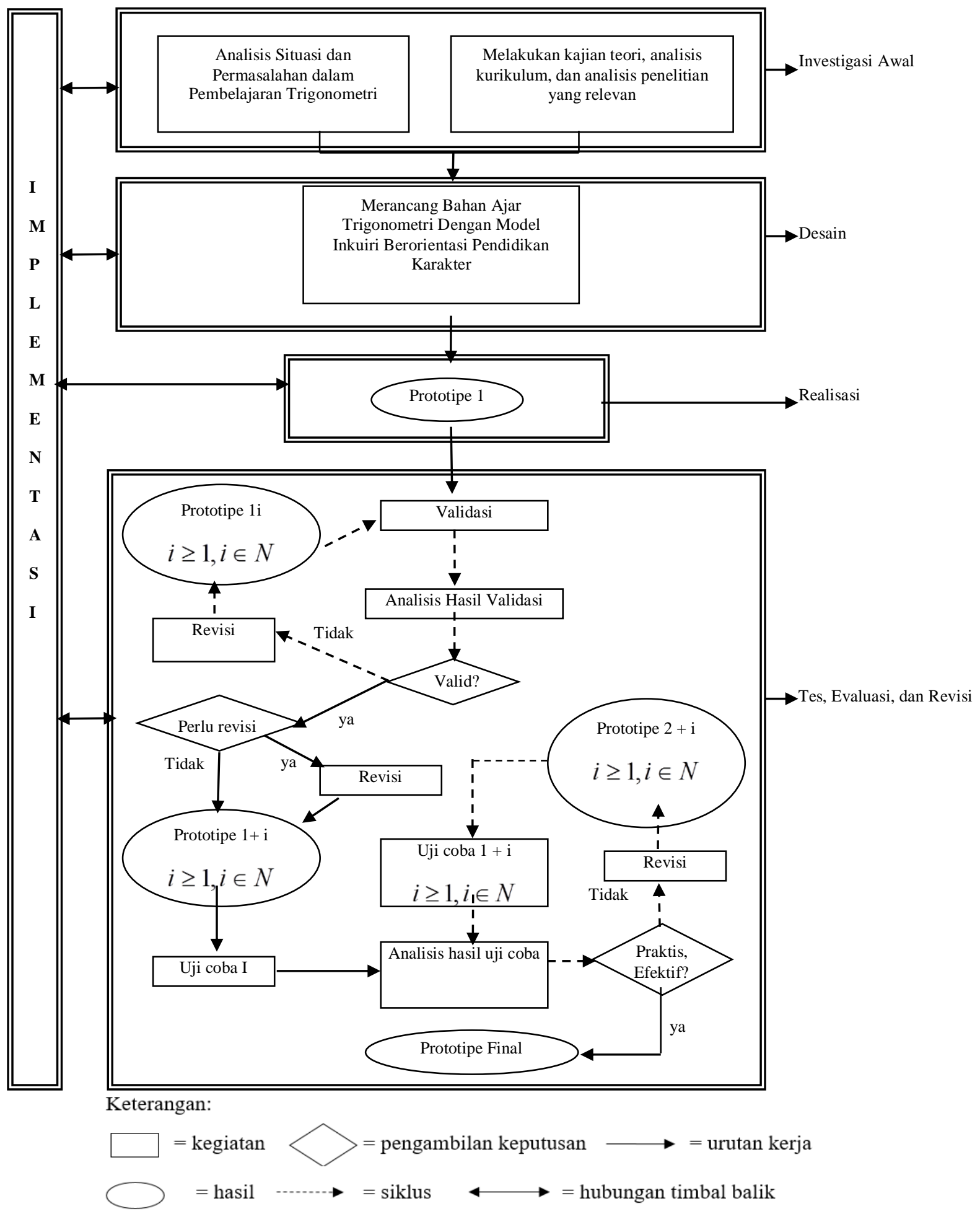

Gambar 1. Skema Prosedur Pengembangan Bahan Ajar

Instrumen yang digunakan dalam penelitian ini adalah lembar validasi bahan ajar. Dalam lembar validasi, pendapat validator dikatagorikan menjadi empat yaitu: sangat valid (skor 4), valid (skor 3 ), tidak valid (skor 2), dan sangat tidak valid (skor 1). Rata-rata skor setiap validator ditentukan dengan cara menjumlahkan skor setiap butir pada lembar validasi kemudian menentukan rata-ratanya. Selain menilai secara kuantitatif, validator juga menilai secara kualitatif dari kualitas bahan ajar. 
Rata-rata skor yang diperoleh dari masing-masing validator dijumlahkan, dan kemudian dirata-ratakan kembali sampai diperoleh rata-rata skor total. Validitas bahan ajar ditentukan dengan mengkonversi rata-rata skor total menjadi nilai kualitatif dengan menggunakan kriteria berikut.

$$
\begin{array}{ll}
3,5 \leq \mathrm{Sr} \leq 4,0 & \text { Sangat Valid } \\
2,5 \leq \mathrm{Sr}<3,5 & \text { Valid } \\
1,5 \leq \mathrm{Sr}<2,5 & \text { Tidak Valid } \\
1,0 \leq \mathrm{Sr}<1,5 & \text { Sangat Tidak Valid }
\end{array}
$$

Bahan ajar dalam penelitian ini minimal harus mencapai kategori valid untuk bisa digunakan dalam pembelajaran yaitu rata-rata skor validator adalah $2,5 \leq \mathrm{Sr}<3,5$.

\section{HASIL DAN PEMBAHASAN}

\section{Hasil}

Sesuai dengan masalah yang ingin dijawab dalam penelitian ini yaitu "bagaimana mengembangkan dan memperoleh bahan ajar trigonometri dengan model inkuiri berorientasi pendidikan karakter yang valid untuk meningkatkan kemampuan berpikir kritis mahasiswa", maka pada kesempatan ini akan disampaikan proses pengembangan dan kualitas bahan ajar yang telah dikembangkan.

Pada tahap investigasi awal dilakukan pengkajian beberapa masalah dalam pembelajaran trigonometri. Untuk data awal mengenai kemampuan berpikir kritis, mahasiswa semester I (ganjil) tahun akademik 2015/2016 kelas A dan kelas B diberikan tes awal untuk kompetensi dasar memahami identitas dan persamaan trigonometri. Data skor tes awal kemampuan berpikir kritis mahasiswa menunjukkan bahwa rata-rata skor kemampuan berpikir kritis mahasiswa untuk kelas A adalah 47,08 dan kelas B adalah 45,64. Jika dikonversi berdasarkan pedoman penilaian kualitatif yang tertera pada Buku Pedoman Studi Undiksha maka rata-rata ini berada pada kategori kurang (D). Selanjutnya dilakukan observasi terhadap kegiatan pembelajaran trigonometri. Berdasarkan kegiatan observasi diketahui bahwa: (1) Mahasiswa kurang termotivasi dalam kegiatan mengevaluasi masalah, mengidentifikasi hal-hal yang akan ditemukan dalam menyelesaikan masalah, menghubungkan keterkaitan antara konsep, menganalisis informasi yang dapat membantu penyelesaian masalah, dan menggunakan berbagai ide untuk menyelesaikan masalah. (2) Mahasiswa hanya menggunakan satu metode dalam menyelesaikan masalah trigonometri. (3) Mahasiswa hanya menunggu mahasiswa yang lebih mampu dalam menyelesaikan masalah. (4) Kurangnya aktivitas belajar tingkat tinggi yang meliputi kegiatan mengevaluasi, mengidentifikasi, menghubungkan, menganalisis, dan memecahkan masalah sehingga mahasiswa cenderung menjadi pasif.

Berdasarkan data informasi pada pusat bagian sistem informasi Pusat Komputer (Puskom) mengenai data hasil belajar mahasiswa pada mata kuliah trigonometri, dan diperoleh data bahwa pada tahun akademik 2013/2014 sebanyak 20,95\% mahasiswa memperoleh nilai A, 33,11\% nilai B, 27,03\% nilai $\mathrm{C}, 10,14 \%$ nilai $\mathrm{D}$, dan $8,78 \%$ nilai $\mathrm{E}$. Sedangkan pada tahun akademik 2014/2015 sebanyak $4,55 \%$ mahasiswa memperoleh nilai A, $22,08 \%$ nilai $\mathrm{B}, 37,01 \%$ nilai $\mathrm{C}, 27,92 \%$ nilai $\mathrm{D}$, dan $8,44 \%$ nilai E. Dari data tersebut pada tahun akademik 2013/2014 sebanyak $45,95 \%$ mahasiswa belum memiliki pemahaman yang baik terhadap konsep trigonometri sedangkan pada tahun akademik 2014/2015 meningkat menjadi 73,37\%. Pada semester genap tahun akademik 2015/2016, untuk dapat menguatkan data, peneliti kembali melakukan investigasi awal terkait materi trigonometri secara umum pada mahasiswa semester II (genap) kelas B yang saat ini mengambil mata kuliah geometri ruang sebanyak 37 mahasiswa pada tanggal 12 April 2016. Hal ini dilakukan mengingat trigonometri menjadi dasar bagi mahasiswa memahami materi geometri ruang. Berdasarkan hasil analisis data skor tes diperoleh rata-rata skor kemampuan berpikir kritis mahasiswa adalah 48,84. Nilai ini tergolong kriteria kurang (D).

Pada tahap desain dilakukan upaya mendesain suatu kemungkinan solusi terhadap masalah yang telah didefinisikan pada tahap investigasi awal. Salah satu pembelajaran yang dapat memaksimalkan peran mahasiswa dalam kegiatan penemuan adalah model pembelajaran inkuiri. Inkuiri dapat dikatakan sebagai cara seseorang untuk mengetahui sesuatu. Proses inkuiri ini mampu mengarahkan dan melibatkan mahasiswa dalam melakukan penyelidikan secara sistematis, kritis, logis, analitis sehingga mereka belajar dengan penuh rasa percaya diri tanpa tekanan. Khan (2012) dalam penelitiannya berjudul "Inquiri-Based Teaching In Mathematics Classroom In A 
Lower Secondary School Of Karachi, Pakistan" menyimpulkan bahwa pembelajaran matematika berbasis inkuiri mampu memberikan kesempatan kepada peserta didik dalam mengeksplorasi konsep matematis dan meningkatkan aktivitas sosial.

Berdasarkan tahapan pembelajaran dengan model inkuiri yaitu (1) tahap perumusan masalah, (2) tahap perumusan hipotesis, (3) melakukan penyelidikan, (4) menganalisis hasil penyelidikan, dan (5) membuat simpulan, maka model inkuiri sangat cocok diterapkan mengingat masalah rendahnya kemampuan berpikir kritis mahasiswa dalam pembelajaran. Tinjauan indikator kemampuan berpikir kritis mahasiswa yang terdiri dari (1) mengevaluasi, (2) mengidentifikasi, (3) menghubungkan, (4) menganalisis, dan (5) memecahkan masalah, maka dapat dijadikan alasan bahwa model inkuiri cocok untuk masalah yang dihadapi mahasiswa Jurusan Pendidikan Matematika pada mata kuliah tigonometri.

Selain masalah tersebut, kurangnya kesadaran mahasiswa akan sikap dan karakter yang tidak baik dalam belajar juga mempengaruhi mahasiswa dalam keberhasilan belajarnya, untuk itu sebagai upaya mengoptimalkan tercapainya tujuan pembelajaran maka model pembelajaran inkuiri diterapkan berorientasi pendidikan karakter. Dalam prakteknya nilai-nilai karakter yang diintegrasikan dipilih berdasarkan analisis kebutuhan masalah yang ditemukan. Adapun karakter yang diduga tidak dibangkitkan dalam belajar adalah karakter rasa ingin tahu, kreatif, kerja keras, tanggung jawab, dan demokratis. Model pembelajaran akan terlaksana dengan maksimal apabila didukung oleh perangkat yang sesuai. Dan untuk membantu mengatasi masalah yang dikemukakan mahasiswa yaitu kurang tersedianya bahan ajar yang membantu mereka dalam membangun konsep trigonometri maka dalam penelitian ini akan dilakukan pengembangan bahan ajar dengan model inkuiri berorientasi pendidikan karakter untuk meningkatkan kemampuan berpikir kritis mahasiswa.

Pada tahap realisasi desain solusi yang telah dirancang direalisasikan dalam bentuk bahan ajar yang masih berupa prototipe 1 yang perlu dilihat aspek validitasnya. Prototipe 1 direalisasikan dengan mengacu pada desain pengembangan menurut Plomp dan model pembelajaran yang diterapkan yaitu model pembelajaran inkuiri berorientasi pendidikan karakter. Selain mengacu pada hal tersebut, prototipe 1 juga direalisasikan dengan mengacu pada karakteristik materi trigonometri dan sasaran untuk mampu meningkatkan kemampuan berpikir kritis mahasiswa. Terdapat tiga kompetensi dasar mata kuliah trigonometri yang diharapkan tercapai menggunakan bahan ajar ini yaitu (1) memahami konsep dasar perbandingan trigonometri, (2) memahami identitas dan persamaan trigonometri, dan (3) memahami aturan sinus, cosinus, dan tangen

Pada tahap tes, evaluasi, dan revisi prototipe 1 yang telah direalisasikan selanjutnya diuji validitasnya oleh 2 orang validator dari Jurusan Pendidikan Matematika Universitas Pendidikan Ganesha Singaraja di mana validator I dipilih berdasarkan pertimbangan pernah meneliti tentang pendidikan karakter, dan validator II pernah meneliti tentang pengembangan bahan ajar berbasis masalah. Jadi kedua validator dapat dinyatakan layak untuk menilai kualitas bahan ajar yang dikembangkan dalam penelitian ini. Berikut disajikan rangkuman hasil penilaian validator pada Tabel 1 berikut ini.

Tabel 1. Rangkuman hasil Validasi Bahan Ajar

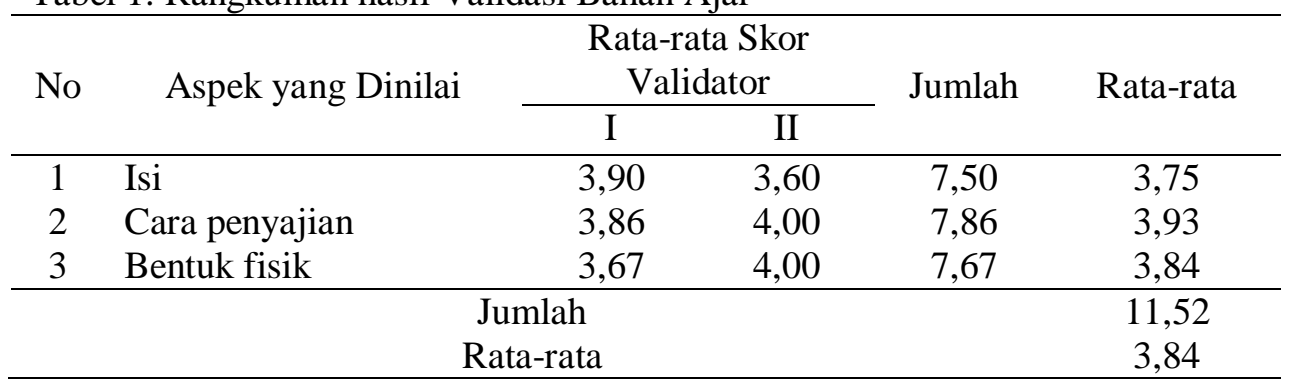

Berdasarkan Tabel 1 dapat disimpulkan bahwa nilai validitas konstruk bahan ajar trigonometri dengan model inkuiri berorientasi pendidikan karakter yang dikembangkan dalam penelitian 
ini memenuhi kriteria sangat valid karena ratarata skor validitasnya berada pada interval $3,5 \leq S r \leq 4,0$. Selain menilai bahan ajar, validator juga menilai instrumen yang akan digunakan dalam penelitian ini seperti angket respons mahasiswa, angket respons dosen, dan lembar pengamatan keterlaksanaan bahan ajar. Rangkuman hasil validasi instrumen tersebut dapat dilihat pada Tabel 2.

Tabel 2. Rangkuman Hasil Validasi Instrumen Penelitian

\begin{tabular}{clcccc}
\hline \multirow{2}{*}{ No } & \multicolumn{2}{|}{ Instrumen Penelitian } & \multicolumn{2}{c}{ Validator I } & \multicolumn{2}{c}{ Validator II } \\
\cline { 3 - 5 } & & Rata-rata & Kriteria & Rata-rata & Kriteria \\
\hline 1 & Angket respons mahasiswa & 3,87 & Layak pakai & 3,60 & Layak pakai \\
2 & Angket respons dosen & 3,93 & Layak pakai & 3,73 & Layak pakai \\
3 & Lembar pengamatan keterlaksanaan & 3,93 & Layak pakai & 3,87 & Layak pakai \\
& bahan ajar & & & & \\
\end{tabular}

Berdasarkan Tabel 2, instrumen yang

akan dipakai pada kegiatan uji coba yang meliputi angket respons mahasiswa, angket respons dosen, dan lembar pengamatan keterlaksanaan bahan ajar telah memenuhi kriteria layak pakai.

Prototipe 2 yang merupakan hasil revisi prototipe 1 berdasarkan saran validator, selanjutnya akan digunakan pada tahap ujicoba terbatas yang akan dilaksanakan pada perkuliahan trigonometri semester I (ganjil) tahun akademik 2016/2017.

\section{Pembahasan}

Prosedur pengembangan bahan ajar trigonometri dengan model inkuiri berorientasi pendidikan karakter dalam penelitian ini telah mengikuti prosedur pengembangan menurut Plomp (1997). Namun, dari lima tahap yang disampaikan Plomp yang terlaksana pada penelitian ini adalah hanya sampai tahap ke empat yaitu tes, evaluasi, dan revisi hingga memperoleh prototipe 2 yang memenuhi kriteria sangat valid dan siap untuk diujicobakan secara terbatas untuk melihat kepraktisan dan efektivitasnya.

Bahan ajar trigonometri dengan model inkuiri berorientasi pendidikan karakter yang disusun dalam penelitian ini memuat masalahmasalah baik masalah yang berkaitan dengan alur penemuan konsep maupun masalah yang berkaitan dengan aplikasi konsep yang telah mahasiswa temukan. Masalah yang dikemukakan pada bahan ajar didesain sedemikian rupa agar mahasiswa terarah dalam melakukan perumusan masalah, perumusan hipotesis, melakukan penyelidikan, menganalisis hasil penyelidikan, dan membuat simpulan. Tentunya hal ini ditunjang dengan membangkitkan nilai-nilai karakter rasa ingin tahu, kreatif, kerja keras, tanggung jawab, dan demokratis yang sejatinya telah ada di dalam individu masing-masing hanya saja kurang diperhatikan dan dibangkitkan dalam kegiatan pembelajaran.

Bahan ajar yang bercirikan model inkuiri berorientasi pendidikan karakter didesain khusus dalam rangka meningkatkan kemampuan berpikir kritis mahasiswa yang dapat dilihat dari indikator mengevaluasi informasi dari masalah, mengidentifikasi ideide yang berkaitan dengan masalah, menghubungkan keterkaitan antara ide-ide yang diperoleh, menganalisis ide yang diperoleh untuk dapat menemukan keterkaitan dengan solusi masalah, dan memecahkan masalah berdasarkan hasil analisis.

Bahan ajar yang berbentuk prototipe 2 ini merupakan penyempurnaan bahan ajar prototipe 1 atas sarang/komentar dari dua orang validator. Bahan ajar dalam penelitian ini juga memuat dua jenis evaluasi di tiap akhir pembelajaran, yaitu evaluasi konsep untuk mengetahui keberhasilan dan kemajuan belajar mahasiswa dalam pembelajaran trigonometri, dan juga evaluasi sikap di mana mahasiswa menilai sendiri sikapnya dalam belajar. Hal ini dirasa perlu karena mahasiswa perlu mengetahui sejauh mana perubahan sikapnya dalam belajar yang dapat menjadi cerminan baginya dalam memupuk kesadaran sikap yang positif dalam belajar. Dengan adanya bahan ajar ini diharapkan kemampuan berpikir kritis mahasiswa dapat meningkat dan terjadi perubahan sikap belajar ke arah yang lebih baik sebagaimana solusi yang diinginkan peneliti, dosen, dan mahasiswa yang telah ditemukan pada tahap investigasi awal.

\section{SIMPULAN}

Berdasarkan pembahasan yang telah disampaikan, simpulan dari penelitian ini 
adalah pengembangan bahan ajar trigonometri dengan model inkuiri berorientasi pendidikan karakter dengan kompetensi dasar memahami konsep dasar perbandingan trigonometri, memahami identitas dan persamaan trigonometri, dan memahami aturan sinus, cosinus, dan tangen. dalam penelitian ini melalui 4 tahap yaitu investigasi awal, desain, realisasi, dan tahap tes, evaluasi, dan revisi sampai akhirnya ditemukan suatu prototipe bahan ajar yang telah memenuhi aspek sangat valid.

\section{DAFTAR RUJUKAN}

Kementerian Pendidikan Nasional. 2011. Panduan Pelaksanaan Pendidikan Karakter. Jakarta: . Badan Penelitian dan Pengembangan Pusat Kurikulum dan Perbukuan.

Khan, A.W. 2012. Inquiry-Based Teaching in Mathematics Classroom in a Lower Secondary School Of Karachi, Pakistan. International Journal of Academic Research in Progressive Education and Development. 1(2). 1-7. Tersedia pada http://www.hrmars.com/admin/pics/667. pdf. Diakses pada tanggal 10 Oktober 2015.

Lickona, T. 2012. Character Matter (Versi Indonesia). Jakarta: Bumi Aksara.

Nieveen, N. 1999. Prototyping to Reach Product Quality. London: Kluwer Academic Publishers.

Nugraha, D. A, Binadja, A, \& [6] Supartono. 2013. Pengembangan Bahan Ajar Reaksi Redoks Bervisi Sets, Berorientasi Konstruktivistik. Journal of Innovative Science Education. 2(1). 2734. Tersedia pada http://journal.unnes.ac.id/sju/index.php/ji se. Diakses pada tanggal 10 Oktober 2015.

Parwati, N. N. 2011. Model Pembelajaran Pemecahan Masalah Berorientasi Pengembangan Pendidikan Karakter (Kajian Teoritis dalam Pembelajaran Matematika). Prosiding Seminar Nasional MIPA. 1(1). 278-283. Tersedia pada

http://ejournal.undiksha.ac.id/index.php/i ndex/search/results. Diakses pada tanggal 10 Oktober 2015.

Plomp, T. 1997. Educational And Training System Design. Enschede: University of Twente, Faculty of Educational Science and Technology.

Sadra, I W. 2007. Pengembangan Model Pembelajaran Matematika Berwawasan Lingkungan dalam Pelatihan Guru Kelas I Sekolah Dasar. Desertasi (tidak diterbitkan). Surabaya: UNESA.

Subarinah, S. 2011. Pengintegrasian Pendidikan Karakter dalam Pembelajaran Matematika SD yang bernuansa PAKEM menggunakan Kompermatik (Kotak Permainan Matematika Realistik. Makalah disajikan dalam Seminar Nasional Matematika dan Pendidikan Matematika, Yogyakata, 3 Desember 2011.

Sudiarta, I. G. P. 2008. Paradigma Baru Pembelajaran Matematika: Membangun Kompetensi Matematis Berpikir Kritis Melalui Pendekatan Open-Ended. Buku Referensi. Singaraja : Penerbit Undiksha.

Zuchdi, Darmiyati. 2012. Implementasi Pendidikan Karakter di Perguruan Tinggi. Makalah disajikan dalam Workshop Redesain Pendidikan Karakter UNY tanggal 5 September 2012. 